\title{
Effect of Sowing Time on Growth, Phenology and Yield Attribute of Summer Groundnut (Arachis hypogaea L.) in Allahabad
}

\author{
Anand Kumar, Manoj Kumar Tripathi* and Virender Pal \\ Department of Environment Science, School of Forestry and Environment, SHIATS-Deemed- \\ To-Be-University, Allahabad, Utter Pradesh (India) \\ *Corresponding author:
}

\section{A B S T R A C T}

\begin{tabular}{|l|}
\hline Key w or d s \\
Groundnut, \\
Variety, \\
Date of sowing, \\
Arachis \\
hypogaea
\end{tabular}

An investigation on effect of sowing time on growth, phenology and yield attribute of summer groundnut (Arachis hypogaea L.) was conducted at Agrometeorological Station Farm, School of Forestry and Environment, SHIATS-Deemed-To-Be-University, Allahabad during crop season 2013. Sixteen treatment combinations with four dates of sowing ( $1^{\text {st }}$ March, $11^{\text {th }}$ March, $21^{\text {st }}$ March and $31^{\text {st }}$ March) and four varieties (HNG-69, R-2 (Girnar-2), HNG-10 and M-13) were tried in split plot design with four replications. The growth parameters, yield attributes and yield in terms of characters like plant population was non-significant and the plant height, number of pods per plants, grain yield and haulm yield were significantly influenced by the dates of sowing. The highest pod yield and haulm yield were obtained from the first date of sowing $\left(1^{\text {st }}\right.$ March) and followed by second date of sowing (11 ${ }^{\text {th }}$ March). The variety HNG-69 gave the highest yield due to more number of pods, number of grains per pod and 100 seed weight, followed by HNG10 variety. The duration of crop growth stages were influenced by the sowing dates. The delay in sowing reduced the total duration of the crop maturity period. The weather condition during the crop season was more or less normal and satisfactory.

\section{Introduction}

Groundnut (Arachis hypogaea L.) is a annual legume crop and a major oilseed crop of tropical and subtropical countries, which is also known as 'peanut', 'earthnut', 'monkey nut' and 'goobers'. It is the $13^{\text {th }}$ most important crop and $4^{\text {th }}$ most oilseed crop of the world. Groundnut is grown during kharif season in areas with the annual rainfall of 600 to $800 \mathrm{~mm}$. it can be very successfully grown in drought prone area during kharif season, but during summer it required irrigation. Ground is a widely adapted to varying agroclimatic conditions and soils, which has made its cultivation possible in most of the tropical and subtropical countries in the world. Groundnut is a $\mathrm{C}_{3}$ plant where photo respiration is very high. Groundnut is a deep rooted a distinct tap root with secondary and deeply spreading roots, make it drought resistant to some extent. Groundnut is a self pollinated crop and pollination takes place early in the morning. The groundnut is mainly grown in kharif season, but due to inadequate, uncertain and erratic rainfall distribution coupled with infestation of pest and diseases, production is less. The cultivation of this crop during summer is much profitable. The information on appropriate time of sowing of 
summer groundnut matching with the weather conditions is not available. The present study was undertaken to identify a suitable variety and find out the optimum date for summer season.

\section{Materials and Methods}

The experiment was conducted at the Agrometeorological Station Farm, School of Forestry and Environment, SHIATS-DeemedTo-Be-University, Allahabad during crop season 2013. The soil of the experiment plot was sandy loam in texture and slightly alkaline in reaction, low in organic carbon and available nitrogen, medium in available phosphorus and potassium status. Sixteen treatment combinations with four dates of sowing ( $1^{\text {st }}$ March, $11^{\text {th }}$ March, $21^{\text {st }}$ March and $31^{\text {st }}$ March) and four varieties (HNG-69, R2(Girnar-2), HNG-10, M-13) were tried in split plot design with four replications.

The keep date of sowing in main plot and varieties as sub plot treatments. The crop was sown in line with spacing of $30 \mathrm{x} 10 \mathrm{~cm}$, using seed rate of $120 \mathrm{~kg} / \mathrm{ha}$ with fertilizer dose of $25 \mathrm{~kg} \mathrm{~N}$ and $50 \mathrm{~kg} \mathrm{P}_{2} \mathrm{O}_{5} / \mathrm{ha}$. Full dose of fertilizer in the form of urea and DAP was applied in furrows before sowing. Two interculturing and two hand weeding were carried out in groundnut crop to maintain weed free condition during crop season. The crop was free form major insect pests by taking suitable plant protection measures. The five plants from net plot were selected randomly and were tagged in each treatment plots for the purpose of measured observation. The treatments were evaluated on the basis of growth parameters like plant population (plant $/ \mathrm{m}^{2}$ ) and plant height measured with measuring scale, on the basis of yield attribute like number of pod per plant pod yield and haulm yield measured with weighing balance per net plot and the same was converted to pod yield per hectare. 100 seeds were counted from the sample and their weight (g) was recorded as test weight of each treatment. Phonological observation measured to decide the crop growth stages five plants from net plot were selected randomly and were tagged in each treatment plots for the purpose of identification of phenological stages. Whenever more than three plants from each plot attained a particular stage for consider for that stage. The same was compared with those from each of the experimental plots to generalize the crop growth stages from each date of sowing were recorded as date of emergence, flowering, pegging, pod development and pod maturity. The keep date of sowing in main plot and varieties as sub plot treatments. The crop was sown in line with spacing of $30 \times 10 \mathrm{~cm}$, using seed rate of $120 \mathrm{~kg} / \mathrm{ha}$ with fertilizer dose of $25 \mathrm{~kg}$ $\mathrm{N}$ and $50 \mathrm{~kg} \mathrm{P}_{2} \mathrm{O}_{5} /$ ha. Full dose of fertilizer in the form of urea and DAP was applied in furrows before sowing. Two interculturing and two hand weeding were carried out in groundnut crop to maintain weed free condition during crop season. The crop was free form major insect pests by taking suitable plant protection measures. The five plants from net plot were selected randomly and were tagged in each treatment plots for the purpose of measured observation. The treatments were evaluated on the basis of growth parameters like plant population (plant $/ \mathrm{m}^{2}$ ), plant height measured with measuring scale, on the basis of yield attribute like number of pod per plant with measuring scale, seed yield and haulm yield measured with weighing balance per net plot and the same was converted to seed yield per hectare. 100 seeds were counted from the sample and their weight ( $\mathrm{g}$ ) was recorded as test weight of each treatment. Phonological observation measured to decide the crop growth stages five plants from net plot were selected randomly and were tagged in each treatment plots for the purpose of identification of phenological stages. Whenever more than 
three plants from each plot attained a particular stage for consider for that stage. The same was compared with those from each of the experimental plots to generalize the crop growth stages from each date of sowing were recorded as date of emergence, pegging, flowering, pod development and pod maturity. The recorded data were subjected to statistical analysis using the analysis of variance technique (Panse and Sukhatme, 1985).

\section{Results and Discussion}

\section{Growth parameters}

The data pertaining to plant population of groundnut are presented in table 1. It is apparent from the data that the sowing dates as well crop varieties did not significantly influence final plant population at the time of maturity. The interaction effect between dates of sowing and varieties for plant population has been found non-significant. The data for those are arranged in table 1 .

The data on plant height recorded at successive stage of groundnut are presented in table 1. It revealed that plant height at different phonological stages viz. emergence, flowering, pegging, pod development and physiological maturity was significantly affected by sowing dates. In general, plant height increased with age of the plant thus maximized at harvest stage. However the margin of increase was the highest between $\mathrm{P}_{2}$ to $\mathrm{P}_{3}$ phenological stages in $\mathrm{D}_{4}$ sowing dates value is $99.14 \%$. Among sowing dates, significantly highest plant height was recorded in $\mathrm{D}_{1}(22.31 \mathrm{~cm})$ followed by $\mathrm{D}_{2}$ $(21.06 \mathrm{~cm})$. However, lowest plant height was recorded in $\mathrm{D}_{4}(17.75 \mathrm{~cm})$ at the time of physiological maturity. Decreased in plant height in late sowing was due to shorter growing period. This finding is also conformity with the findings of Ahmed et al.,
(1992). The crop varieties also significantly influenced the plant height at different phonological stages (Table 2). Among varieties, significantly highest plant height was obtained by variety $\mathrm{V}_{4}(21.75 \mathrm{~cm})$ followed by $\mathrm{V}_{1}(20.88 \mathrm{~cm}), \mathrm{V}_{3}(19.50 \mathrm{~cm})$ and $\mathrm{V}_{2}(18.50 \mathrm{~cm})$ respectively (Table 2). This finding is also conformity with the findings of Kulandaiavelu and Morachan et al., (1983). The interaction effect between date of sowing and varieties was found to be significant at pod development stage but at other stages interaction was non-significant. The data for those are arranged in table 2.

\section{Yield attributes}

\section{Number of pods/ plant}

The pertinent data on number of pod per plant are furnished in Table 3 . The results revealed that number of pods was significantly affected by different sowing dates. The highest no. of pods/plant was observed in $\mathrm{D}_{1}$ (17.56) followed by $\mathrm{D}_{2}$ (15.94) sown conditions (15.94). However, the lowest number of pods/plant (12.56) was recorded in $\mathrm{D}_{4}$ sowing.

The margin of increase in number of pods/plant with $\mathrm{D}_{1}$ sown conditions over $\mathrm{D}_{2}$ was found to be $9.31 \%$. The varieties also significant affected the number of pods/plant.

The highest number of pods/plant was observed in $\mathrm{V}_{1}$ (16.75) followed by $\mathrm{V}_{4}$ (16.00) and lowest number of pods/plant was observed in $V_{3}$ (13.50). The margin of increase in number of pods/plant of variety $\mathrm{V}_{1}$ over $\mathrm{V}_{4}$ was $4.69 \%$ (Table 3 ). These finding are in close agreement with those obtained by Naphade et al., (1990). The effect of sowing dates $\mathrm{x}$ varieties interaction effect was found to be non-significant for pods/plant and the pertinent data are managed in Table 3. 


\section{Test weight}

The pertinent data on test weight of groundnut are furnished in table 3. The test was significantly influenced by sowing dates. The highest value was recorded in $\mathrm{D}_{1}$ (43.84 gm) followed by $\mathrm{D}_{2}(43.03 \mathrm{gm})$. The lowest value was recorded in $\mathrm{D}_{4}$ sowing (40.48 gm). However, different varieties showed significant influence over test weight. The variety $\mathrm{V}_{1}(48.37 \mathrm{gm})$ recorded highest test weight followed by $\mathrm{V}_{2}(42.69 \mathrm{gm})$ and the lowest in variety $\mathrm{V}_{3}(37.80 \mathrm{gm})$ (Table 3$)$. The margin of increase in test weight with $\mathrm{V}_{3}$ over remaining varieties varies between $6.87 \%$ and $21.85 \%$. The interaction effect between date of sowing and varieties was found to be significant for test weight. The data for those are arranged in table 3 .

\section{Pod yield}

The data on pod yield are presented in Table 3. Different dates of sowing significantly influenced pod yield. The $\mathrm{D}_{1}$ sowing highest pod yield $(1552.50 \mathrm{~kg} / \mathrm{ha})$ followed by $\mathrm{D}_{2}$ $(1374.38 \mathrm{~kg} / \mathrm{ha})$. However, $\mathrm{D}_{4}$ sowing recorded the lowest pod yield (1144.13 $\mathrm{kg} / \mathrm{ha}$ ). The $\mathrm{D}_{1}$ sowing recorded 12.96 to $35.69 \%$ margin of increase in pod yield than other sowing environments, the pod yield decreased significantly in late sown conditions. This might be due to higher rainfall during pod development stage of the crop which increased the vertical growth of the plant causing inferior development of yield attributes and hence, lower pod yield. These results are in line with those of Padhi et al., (1994). Among the pod yield was significant influenced the crop varieties. The highest pod yield of was obtained by the variety $\mathrm{V}_{1}(1494.75 \mathrm{~kg} / \mathrm{ha})$ followed by $\mathrm{V}_{3}$ $(1362.50 \mathrm{~kg} / \mathrm{ha})$ and the lowest pod yield was obtained by the variety $\mathrm{V}_{4}(1159.50 \mathrm{~kg} / \mathrm{ha})$. The interaction effect between date of sowing and different varieties was found to be significant for pod yield (Table 3).

\section{Haulm yield}

The data on haulm yield are presented in Table 3. Different dates of sowing significantly influenced the haulm yield. The highest haulm yield was recorded in $\mathrm{D}_{1}$ $(1973.90 \mathrm{~kg} / \mathrm{ha})$ followed by $\mathrm{D}_{2}(1847.80$ $\mathrm{kg} / \mathrm{ha}$ ). The lowest haulm yield was recorded under $\mathrm{D}_{4}(1627.705 \mathrm{~kg} / \mathrm{ha})$. Among varieties, the significant highest haulm yield was obtained by $\mathrm{V}_{1}(2019.13 \mathrm{~kg} / \mathrm{ha})$ followed by $\mathrm{V}_{2}(1911.56 \mathrm{~kg} / \mathrm{ha})$. However, significantly lowest haulm yield of was recorded by variety $\mathrm{V}_{4}(1553.38 \mathrm{~kg} / \mathrm{ha})$ (Table 3). The interaction effect between dates of sowing and different varieties was found to be non significant for haulm yield (Table 3 ). The results are with the conformity with the findings of Jadhav et al., (1990).

\section{Shelling percentage}

The data on shelling percentage are presented in table 3. Shelling percentage was significantly influenced by different dates of sowing. The highest shelling percentage was recorded in $\mathrm{D}_{1}(67.43 \%)$ followed by $\mathrm{D}_{2}$ $(65.79 \%)$. The lowest shelling percentage $(63.98 \%)$ was recorded under $\mathrm{D}_{4}$ sowing condition. The shelling percentage was significantly affected by crop varieties. The highest shelling percentage was obtained by variety $\mathrm{V}_{1}(70.59 \%)$ followed by $\mathrm{V}_{2}(65.33$ $\%)$. However, the lowest shelling percentage was obtained by variety $\mathrm{V}_{2}$ value is $61.35 \%$ (Table 3). The interaction effect between dates of sowing and varieties was found to be significant. The data for those are arranged in table 3.

\section{Oil content}

The data for oil content are furnished in Table 3 . The oil content was significantly influenced by different sowing dates. The highest oil content was recorded in $\mathrm{D}_{2}(46.96 \%)$ 
followed by $\mathrm{D}_{3}(45.22 \%)$. The lowest value was recorded in $\mathrm{D}_{4}$ sowing (40.88). The oil content was non-significantly affected by different crop varieties. The interaction effect between date of sowing and different varieties was found to be significant for oil content. The data for those are arranged in table 3.

The percent increase in seed yield by HNG215 was 8.84 percent higher over HNG-10 variety. This is due to cumulative effect of improvement in growth and yield attributes such as plant population, plant height and number of pods per plant. These findings in the present investigation are in accordance with the findings of Bhosale et al., (1986), More and Khade (1987), Jadhav et al., (1990), Guggari et al., (1994) in the summer groundnut.

\section{Crop phenology}

The observation on crop phenological events reflects the influence of weather elements on crop growth and development. In the present study, the occurrence of different phenological events viz., germination, flowering, pegging, pod development, pod maturity was recorded. The phenological calendar for groundnut crop for four dates of sowing in the present investigation is presented in Table 3. The data pertaining to days to attain $50 \%$ flowering has been presented in table 1. Different dates of sowing significantly influenced $50 \%$ flowering. The highest value was recorded in $\mathrm{D}_{1}$ (43.75 days) followed by $\mathrm{D}_{2}$ (42.38 days). The lowest value was recorded in $\mathrm{D}_{4}$ (37.81 days). Different varieties also showed significant influence on days taken to attain $50 \%$ flowering. The variety $\mathrm{V}_{1}$ took the highest days (44.75 days) followed by $\mathrm{V}_{2}$ (41.25 days) to attain $50 \%$ flowering. However, the lowest days were taken by variety $\mathrm{V}_{4}(38.75$ days) to attain $50 \%$ flowering. The data for those are arranged in table 1. The data pertaining to days taken to attain maturity has been presented in table 1. Different sowing dates significantly influenced crop maturity. The highest days was recorded in $\mathrm{D}_{1}$ sowing to attain maturity (122.06 days) followed by $\mathrm{D}_{2}$ sowing (116.44 days). Where, as $\mathrm{D}_{4}$ sowing recorded minimum days to maturity (101.75 days). Different varieties also showed significant influence on days taken to maturity. The highest days were taken by variety $\mathrm{V}_{1}$ (117.06 days) followed by $\mathrm{V}_{2}$ (115.19 days). The lowest value was recorded in variety $\mathrm{V}_{4}$ (110.25 days). The data for those are arranged in table 1 . The interaction effect between dates of sowing and varieties to reach maturity has been found nonsignificant. The data for those are arranged in table 1 .

The days to maturity decreased gradually with the delay in sowings. This may be due to increase in temperature and photothermal environment encountered by the crop during the growth period. However, reduction in duration (101.75 days) under fourth date sowing may be mainly due to exposed to higher maximum temperature $\left(45.2^{\circ} \mathrm{C}\right)$ at flowering stage.

\section{Correlation studies}

The correlation study between weather parameters (like maximum temperature, minimum temperature, mean temperature, temperature range, relative humidity-I \&II and bright sunshine hours) with different phenophases was carried out and presented in table 4 .

\section{Weather parameters vs. phenophases}

The results showed that a highly significant and negative correlation was observed between maximum temperature and different phenophases (emergence, flowering, pegging) of crop. 
Table.1 Effect of sowing dates on plant population and phenology during crop season 2013

\begin{tabular}{|c|c|c|c|}
\hline Treatment & Plant population & Days to $50 \%$ flowering & Days to maturity \\
\hline \multicolumn{4}{|c|}{ Sowing dates (D) } \\
\hline $\mathrm{D}_{1}$ & 8.06 & 43.75 & 122.06 \\
\hline $\mathrm{D}_{2}$ & 8.00 & 42.38 & 116.44 \\
\hline $\mathrm{D}_{3}$ & 8.31 & 40.81 & 113.00 \\
\hline $\mathrm{D}_{4}$ & 7.88 & 37.81 & 101.75 \\
\hline F-test & NS & $\mathrm{S}$ & $\mathrm{S}$ \\
\hline S.Em. \pm & - & 0.344 & 2.503 \\
\hline C.D. at $5 \%$ & - & 0.777 & 5.662 \\
\hline C.V.\% & 2.71 & 0.59 & 1.56 \\
\hline \multicolumn{4}{|c|}{ Varieties (V) } \\
\hline $\mathrm{V}_{1}$ & 8.50 & 44.75 & 117.06 \\
\hline $\mathrm{V}_{2}$ & 8.13 & 41.25 & 115.19 \\
\hline $\mathrm{V}_{3}$ & 7.75 & 40.00 & 110.75 \\
\hline $\mathrm{V}_{4}$ & 7.88 & 38.75 & 110.25 \\
\hline F-test & NS & $\mathrm{S}$ & $\mathrm{S}$ \\
\hline S.Em. \pm & - & 0.338 & 1.715 \\
\hline C.D. at $5 \%$ & - & 0.686 & 3.484 \\
\hline C.V.\% & 1.42 & 0.670 & 1.140 \\
\hline \multicolumn{4}{|c|}{ Interaction (D X V) } \\
\hline F-test & NS & NS & $\mathrm{NS}$ \\
\hline S.Em. \pm & - & - & - \\
\hline
\end{tabular}


Table.2 Effect of sowing dates on plant height at different phonological stages during crop season 2013

\begin{tabular}{|c|c|c|c|c|}
\hline \multirow{2}{*}{ Treatment } & \multicolumn{4}{|c|}{ Plant height (cm) } \\
\hline & Flowering & Pegging & Pod development & Pod Maturity \\
\hline \multicolumn{5}{|c|}{ Sowing dates (D) } \\
\hline $\mathrm{D}_{1}$ & 10.75 & 17.94 & 21.72 & 22.31 \\
\hline $\mathrm{D}_{2}$ & 10.06 & 17.44 & 19.56 & 21.06 \\
\hline $\mathrm{D}_{3}$ & 8.75 & 16.94 & 18.06 & 19.50 \\
\hline $\mathrm{D}_{4}$ & 8.13 & 16.19 & 16.50 & 17.75 \\
\hline F-test & $\mathrm{S}$ & $\mathrm{S}$ & $\mathrm{S}$ & $\mathrm{S}$ \\
\hline S.Em. \pm & 0.431 & 0.354 & 0.396 & 0.518 \\
\hline C.D. at $5 \%$ & 0.975 & 0.800 & 0.897 & 1.172 \\
\hline C.V.\% & 3.24 & 1.46 & 1.48 & 1.82 \\
\hline \multicolumn{5}{|l|}{ Varieties (V) } \\
\hline $\mathrm{V}_{1}$ & 9.19 & 16.56 & 19.53 & 20.88 \\
\hline $\mathrm{V}_{2}$ & 7.63 & 15.50 & 17.25 & 18.50 \\
\hline $\mathrm{V}_{3}$ & 8.69 & 16.69 & 18.31 & 19.50 \\
\hline $\mathrm{V}_{4}$ & 12.19 & 19.75 & 20.75 & 21.75 \\
\hline F-test & $\mathrm{S}$ & S & S & S \\
\hline S.Em. \pm & 0.467 & 0.392 & 0.326 & 0.349 \\
\hline C.D. at $5 \%$ & 0.949 & 0.796 & 0.661 & 0.709 \\
\hline C.V.\% & 4.41 & 1.55 & 1.96 & 1.25 \\
\hline \multicolumn{5}{|c|}{ Interaction (D X V) } \\
\hline F-test & NS & NS & S & NS \\
\hline S.Em. \pm & - & - & 0.651 & - \\
\hline C.D. at $5 \%$ & - & - & 1.323 & - \\
\hline
\end{tabular}


Table.3 Effect of sowing dates on yield attributes, yield and oil content of groundnut during crop season 2013

\begin{tabular}{|c|c|c|c|c|c|c|}
\hline Treatment & $\begin{array}{l}\text { No. of pod } \\
\text { /plant }\end{array}$ & $\begin{array}{l}\text { Test weight } \\
\text { (gm) }\end{array}$ & $\begin{array}{l}\text { Shelling } \\
\text { Percent (\%) }\end{array}$ & $\begin{array}{l}\text { Pod yield } \\
(\mathrm{kg} / \mathrm{ha})\end{array}$ & $\begin{array}{l}\text { Haulm yield } \\
\text { (kg/ha) }\end{array}$ & $\begin{array}{l}\text { Oil content } \\
(\%)\end{array}$ \\
\hline \multicolumn{7}{|c|}{ Sowing dates $(\mathrm{D})$} \\
\hline$D_{1}$ & 17.56 & 43.84 & 67.43 & 1552.50 & 1973.9 & 43.75 \\
\hline$D_{2}$ & 15.94 & 43.03 & 65.79 & 1374.38 & 1847.8 & 46.96 \\
\hline $\mathrm{D}_{3}$ & 14.69 & 42.08 & 64.42 & 1243.88 & 1751.1 & 45.22 \\
\hline $\mathrm{D}_{4}$ & 12.56 & 40.48 & 63.98 & 1144.13 & 1627.7 & 40.88 \\
\hline F-test & $\mathrm{S}$ & $\mathrm{S}$ & $\mathrm{S}$ & $\mathrm{S}$ & $\mathrm{S}$ & $\mathrm{S}$ \\
\hline S.Em. \pm & 0.253 & 0.331 & 0.231 & 24.237 & 13.8 & 0.582 \\
\hline C.D. at $5 \%$ & 0.573 & 0.749 & 0.523 & 54.825 & 31.36 & 1.317 \\
\hline C.V.\% & 1.18 & 0.55 & 0.25 & 1.29 & 0.54 & 0.93 \\
\hline \multicolumn{7}{|c|}{ Varieties $(\mathbf{V})$} \\
\hline $\mathrm{V}_{1}$ & 16.75 & 48.37 & 70.59 & 1494.75 & 2019.1 & 44.26 \\
\hline $\mathrm{V}_{2}$ & 14.50 & 42.69 & 65.33 & 1298.13 & 1911.5 & 43.71 \\
\hline $\mathrm{V}_{3}$ & 13.50 & 37.80 & 64.34 & 1362.50 & 1716.5 & 44.25 \\
\hline $\mathrm{V}_{4}$ & 16.00 & 40.59 & 61.35 & 1159.50 & 1553.3 & 44.58 \\
\hline F-test & $\mathrm{S}$ & $\mathrm{S}$ & $\mathrm{S}$ & $\mathrm{S}$ & $\mathrm{S}$ & NS \\
\hline S.Em. \pm & 0.319 & 0.272 & 0.228 & 23.95 & 18.73 & - \\
\hline C.D. at $5 \%$ & 0.647 & 0.553 & 0.463 & 48.66 & 38.06 & - \\
\hline C.V.\% & 1.82 & 0.83 & 0.40 & 4.48 & 0.91 & 1.52 \\
\hline \multicolumn{7}{|c|}{ Interaction (D X V) } \\
\hline F-test & NS & $\mathrm{S}$ & $\mathrm{S}$ & $\mathrm{S}$ & NS & $\mathrm{S}$ \\
\hline S.Em. \pm & - & 0.544 & 0.456 & 47.906 & - & 1.242 \\
\hline C.D. at $5 \%$ & - & 1.105 & 0.926 & 97.320 & - & 2.522 \\
\hline
\end{tabular}

Table.4 Phenophase wise correlation between yield and average weather parameter groundnut during crop season 2013

\begin{tabular}{llllll}
\hline $\begin{array}{l}\text { Weather } \\
\text { parameters }\end{array}$ & \multicolumn{5}{c}{ Phenophases } \\
\cline { 2 - 5 } & Emergence & Flowering & Pegging & $\begin{array}{l}\text { Pod } \\
\text { development }\end{array}$ & Pod maturity \\
\hline Tmax & $-0.6362^{* *}$ & $-0.7991^{* *}$ & $-0.8122^{* *}$ & $0.5828^{*}$ & 0.3027 \\
Tmin & $-0.7468^{* *}$ & $-0.8380^{* *}$ & $-0.6428^{* *}$ & $-0.8398^{* *}$ & $-0.8284^{* *}$ \\
RH-I & 0.0614 & $0.6623^{* *}$ & $-0.8046^{* *}$ & $0.8321^{* *}$ & $-0.8141^{* *}$ \\
RH-II & 0.0943 & $0.7868^{* *}$ & $0.7911^{* *}$ & $-0.5644^{* *}$ & $-0.8153^{* *}$ \\
BSS & 0.3902 & $-0.7911^{* *}$ & $-0.8349 * *$ & $0.6094 *$ & $0.5125^{*}$ \\
\hline
\end{tabular}


A highly significant and negative correlation was also observed between minimum temperature and different phenophases during emergence, flowering, pegging and pod development stages of crop growth. A highly significant and positive correlation between morning relative humidity and different phenophases was noted during flowering (0.66), pod development stage (0.83). A highly significant and negative correlation between morning relative humidity and pegging stage $(-0.80)$ and pod maturity (0.81 ) was observed.

A highly significant and positive correlation values between evening relative humidity and phenophases was noticed during flowering (0.78) and pegging stage (0.79). Highly significant and negative correlations between evening relative humidity and pod development and pod maturity stages were observed. Significantly positive correlation values between bright sun shine hours and different phases were noticed during pod development (0.61) and pod maturity stage (0.51). However, a highly negative correlation between bright sun shine hours and pegging stage was observed.

\section{References}

Ahmed, M. (1992). Performance of groundnut (Arachis hypogaea) varieties as affected by date of sowing in Assam. Ind. J. of
Agron.,37(2): 382-383.

Bhosale, S. G., Shelke, V. B., Dhoble, M. V. and Raikheikar, S. V. (1986). Effect of sowing dates on groundnut varieties in summer season. J. Mah. Agric. Univ.,12 (2): 197-198.

Guggari, A. K., Manjappa, P. S., Dharmaraj, Y. B., Palled, Y. B. and Rao, S. (1994). Performance of groundnut varieties under different dates of sowing during rabi/summer season. J. Oilseed Res.,11(2):201-203.

Jadhav, A. S. Mundhe, M. S and Gaikwad, C. B. (1990). Influence of sowing dates of summer groundnut varieties. J. Mah. Agric. Univ.,15(2): 214-217.

Kulandaiavelu, R. and Morachan, Y. B.(1983) Influence of weather on pod yield and growth attributes in bunch groundnut. Turrialba.,33(3) 332-334.

More, V. D. and Khade, K. K. (1987). The yield performance different varieties of groundnut under of varying dates of sowing grown during summer season. $J$. Oilseed Res.4 (2):275-278.

Naphade, D. S. Sawarkar, P. G. and Kene, H. K. (1990). Effect of sowing dates on s yield of summer groundnut. J. Mah. Agric. Univ., 18(1): 157.

Padhi, A. K. (1994). Response of groundnut (Arachis hypogaea $\mathrm{L}$ ) varieties to time of sowing under rainfed condition. $J$. Oilseeds Res.,11 (1): 132-133.

\section{How to cite this article:}

Anand Kumar, Manoj Kumar Tripathi and Virender Pal. 2017. Effect of Sowing Time on Growth, Phenology and Yield Attribute of Summer Groundnut (Arachis hypogaea L.) in Allahabad. Int.J.Curr.Microbiol.App.Sci. 6(4): 2357-2365. doi: https://doi.org/10.20546/ijcmas.2017.604.275 